DOI: http://dx.doi.org/10.30970/fpl.2020.133.3182

\title{
“БОЛІЛА БОЛЕМ СЛОВА НАШОГО...”: АНАЛІЗ НАУКОВОГО ДОРОБКУ ПРОФЕСОРА РОКСОЛАНИ ЗОРІВЧАК У СЛОВОЗНАВСТВІ
}

\author{
Руслана Ситар \\ Львівський національний університет імені Івана Франка, \\ вул. Університетська, 1, м. Львів, Украӥна, 79000 \\ sytarruslana212@gmail.com
}

\begin{abstract}
У статті розкрито науковий доробок професора Роксолани Зорівчак у Словознавстві, яка вміло продовжила працю свого вчителя Юрія Жлуктенка і перша на теренах України подала вичерпний, на той час, перелік англомовних перекладів “Слова”, аналізуючи кожен. Свої дослідження Роксолана Зорівчак не обмежила лише перекладами, а змогла зібрати та проаналізувати критичні праці над цією пам'яткою Середньовіччя. Не могла оминути увагою дослідниця і питання автентичності твору та його місця в контексті культури Київської Русі.

Ключові слова: Англомовна Словіана, переклад, давньоруський епос, автентичність, “Слово о полку Ігоревім", темні місця.
\end{abstract}

Студії над “Словом” з перекладознавчого погляду започаткував проф. Ю. Жлуктенко. Так, до 800-ї річниці “Слова” перекладознавчий збірник Київського (на той час) державного університету імені Т. Шевченка публікує його статтю “Слово о полку Игореве в английском переводе” [1]. Позбавлений доступу до більшості перекладів, дослідник зробив глибоко професійний аналіз, на жаль, лише одного перекладу твору, виконаного I. Петровою у зіставленні з оригіналом, та побіжно згадав про інші переклади, зокрема Д. Ворда, В. Кіркконела - П. Крата і В. Набокова та подав їхній бібліографічний опис. Навіть ця згадка була дуже сміливим (i, очевидно, ризикованим) кроком проф. Ю. Жлуктенка - ученого, який за словами Р. Зорівчак, завжди мислив категоріями української науки.

Роксолана Зорівчак продовжила працю свого учителя в царині Словознавства i уже в нових умовах вільної України з'явилися ії відповідні статті [2; 3; 13].

У праці "The Ihor Song" in the Anglophone world: Translation, scholarship" [13] вона зосереджує свою увагу на популярності пам'ятки в англомовному світі, зокрема на іiі перекладах, стисло характеризуючи кожен з них. Дослідниця зазначає, що “Слово”, як і будь-який інший твір, перекладати надзвичайно важко. Перші труднощі з'являються при відтворенні власних назв, не кажучи вже про експресивний синтаксис!

Англомовні перекладачі, звичайно, могли скористати з існування чималої кількості перекладів різними мовами (хоча кожен перекладач торує своєю, ще незвіданою стежкою). Серед англомовних перекладів дослідниця першим називає прозовий

(C) Ситар P., 2020 
переклад Л. Магнуса 1915 р. (цей автор також відомий перекладами української поезії, а саме твора Т. Шевченка “Минають дні, минають ночі...”). Окрім оригінального тексту та перекладу, видання містило також передмову, глосарій перекладача та коментарі ${ }^{1}$. Незабаром, у 1918-1919 рр., з'явились ще два, також прозові переклади “Слова” Хелен де Вере Бокларк², без будь-якої передмови, та Елігзандера й Ванди Петрункевичів ${ }^{3}$.

Двічі звертався до перекладу “Слова” відомий канадський професор В. Кіркконел: у 1947 р. він уперше переклав твір у співавторстві з українським літератором у Канаді П. Кратом ${ }^{4}$. Переклад побачив світ завдяки сприянню Українського інституту імені П. Могили. Роксолана Зорівчак висловлювала критичні зауваги щодо перекладу цього твору чотиристопним хореєм, що зовсім не відповідає ритмічному колориту пам’ятки, адже “Слово” - твір, що не має певної віршової форми чи розміру, а складається з ритмічних одиниць різної довжини. До того ж, переклад містив надто багато пропусків. Однак важливим є те, що В. Кіркконел та П. Крат - перші серед англомовних перекладачів “Слова” - розглядають його як пам’ятку давньоруської, а не давньоросійської літератури, що відображено і в мові перекладу (the land of Russ, the Russ princes). Другий переклад “Слова”, виконаний В. Кіркконелом у співавторстві iз канадцем українського походження, проф. К. Андрусишином (переклад не містить жодних пропусків) $)^{5}$ побачив світ 1963 р. в укладеній та перекладеній ними антології “Українські поети, 1189-1962”, що відображає розвиток української літератури протягом восьми століть.

1952 р. до перекладу “Слова” англійською мовою звертається відомий перекладач, письменник, критик В. Набоков ${ }^{6}$. Цей переклад мав практичну мету - ознайомити англомовного читача, зокрема студентів із літературною пам'яткою Древньої Русі. Видання, збагачене передмовою та коментарями перекладача, алфавітним переліком згаданих у “Слові" князів, географічною картою Русі XII ст. та генеалогічною схемою, побачило світ у Нью-Йорку та Торонто 1960 р. У передмові, окрім історії походу Ігоря Святославовича та фактів щодо відкриття пам'ятки i iii перших видавців, В. Набоков подає аналіз композиції твору і деякі особливості його поетики - зображення в “Слові” природи і тваринного світу, функції художнього контрасту

The tale of Igor / Adapted from the Old Russian legend by Helen de Vere Beauclerk. Lnd.: Beaumont, 1918. $79 \mathrm{p}$.

2 The tale of Igor / Adapted from the Old Russian legend by Helen de Vere Beauclerk. Lnd.: Beaumont, 1918. 79 p.

3 The lay of the war-ride of Igor. Transl. by A. \& W. Petrunkevich. The Poet Lore, 1919. Vol. 30. P. 289-303.

4 Prince Ihor's raid against the Polovtsi. Transl. By P. C. Crath; Versified by W. Kirkconnell. Saskatoon, Sask.: The Mohyla Ukrainian Institute, 1947. 14 p.

5 The tale of the campaign of Ihor, son of Sviatoslav, grandson of Oleh. The Ukrainian poets, 1189-1962. Sel. and transl. into English verse by C. H. Andrusyshen and W. Kirkconnell. Toronto : Univ. of Toronto press, 1963. P. 3-21.

6 The song of Igor's campaign: An epic of the twelfth century. Transl. from the Old Russian by V. Nabokov. New York: Vintage Books. A Division of Random House. Toronto : Random House of Canada, 1960. 135 p. 
між світлом і темрявою; аналізуючи Плач Ярославни, дослідник зіставляє його із західноєвропейськими баладами. Текст перекладу В. Набоков розбиває на 860 строф, використовуючи перше видання твору як оригінал. Коментарі до “Слова” перекладача грунтуються як на працях англійських та американських дослідників, зокрема на книзі Р. Якобсона і М. Шефтеля “La Gestedu Prince Igor” 1948 р. і на перекладі Л. Магнуса 1915 р., так і на російських виданнях та дослідженнях - Д. Ліхачова, Л. Дмітрієва, В. Ржиги та ін. [3]. У своїй розвідці Роксолана Зорівчак зазначає, що “Слово” цікавило перекладача не як поетичний літопис свого часу, не як твір великої політичної та патріотичної ваги, а, радше, як витвір позачасової краси, який В. Набоков, можливо, й надто буквально намагався донести до англомовного читача того часу й далеко не “засобами сучасної розвинутої поетичної мови” [3, с. 118]. Цей переклад заслуговує на існування й повноцінно займає своє місце в англомовній Словіані та є цікавим дослідним матеріалом з перекладознавчого погляду. Вдруге переклад опубліковано 1961 р. у Лондоні.

1966 р. з'явився переклад Д. Ворда'. Уперше він переклав “Слово” у 1954 р., причому текст був розповсюджений у вузькому колі знайомих. Пізніше переклад слугував додатком до доповіді Д. Ворда на IV Міжнародному конгресі славістів. Перекладаючи твір удруге, він вніс деякі зміни, а також додав заголовки, чим і намагався “адаптувати” пам’ятку до англомовного читача (Москва, 1958 р.).

У 1973 році опубліковано переклад Р. Гауза², а у 1979 р. - англомовний переклад Р. Мена 3 . Стилістику староруського твору дослідник розглядає в контексті загальноєвропейської епічної традиції. Значне місце в дослідженнях Р. Мена присвячено трактуванню імені Трояна. На його гадку, це язичницький бог, втілений в образі триголового змія. На підтвердження своїх поглядів дослідник наводить дані $з$ слов'янської топоніміки, російського, південнослов'янського та румунського фольклору, а також лінгвістичні аргументи [2, с. 307].

За два століття від першого знайомства зі “Словом” у нашій країні і у всьому світі 3'явились його численні переклади і переспіви, які не увійшли уже до анотованих праць Роксолани Зорівчак. Це, скажімо, переклад П. Салевича, що супроводжується детальними і грунтовними коментарями [4], а також англомовний переклад Б. Яценка [5], знайомством з яким автор цієї розвідки завдячує Роксолані Петрівні.

Дебютував Б. Яценко як дослідник “Слова” в 1970 р. статтею “Про Троянь” у журналі “Архіви України” [10], в якій він розв’язує надзвичайно складну історичну загадку Трояна. Ця лексема згадується чотири рази в “Слові”: “рища в тропу Трояню”, “Были вһчи Трояни”, “на землю Трояню”, “на седьмомъ вһцһ Трояни”, але жодна 3 цих фраз не дає чіткого поняття про Трояна. 1976 р. в “Трудах Отдела древнерусской литературы Института русской литературы (Пушкинский Дом) АН СССР” з'явилась

1 The tale of the host of Igor. Transl. by D. Ward. Forum for Modern Language Studies. 1966. April. Vol. 2. № 2. P. 160-174.

2 The tale of the campaign of Igor. Transl. by R. C. Howes. New York : W. W. Norton \& Co, Inc, 1973. $72 \mathrm{p}$.

3 The song of Prince Igor. Transl., introd. and comm. by R. Mann. Eugene, Oregon : Vernyhora Press, 1979. $89 \mathrm{p}$. 
наступна стаття Б. Яценка: “Кто такой Борис Вячеславич “Слова о полку Игореве”?”[6], у якій автор, ретельно досліджуючи літописні джерела, спробував встановити особу і родовід князя Бориса Вячеславича, про якого згадується в “Слові”. Структури тексту “Слова" торкається Б. Яценко й у статті "Про “золоте слово" Святослава Київського" та висловлює кілька міркувань щодо його складу та значення в історико-літературному аналізі пам'ятки [9]. У кількох роботах Б. Яценко аналізує літописні оповіді про похід, зіставляючи їх зі “Словом о полку Ігоревім” [7; 8].

Роксолана Зорівчак висловлювала свій жаль 3 приводу незначної кількості критичних праць про переклади Слова [13]. 3 тих, що існували на той час, дослідниця виділяє статтю Д. Ворда про працю над перекладом "On translating "Slovo o polku Igoreve" 10 , у якій дослідник детальніше зупиняється на так званих “темних місцях" твору, на відтворенні семантики експресивного синтаксису, зокрема, порядку слів, паралельних синтаксичних конструкцій, архаїзмів, словесних образів. В останньому розділі статті автор пропонує свої зразки розв'язання окремих перекладацьких проблем.

У контексті критичних праць згадує дослідниця і дисертацію А. Бакер "Sea and steppe imagery in Old English and Old Russian epic" 1976 p. Автор на основі образів моря та степу в давньоанглійському (“Беовульф”) та давньоросійському епосі (“Слово”) доводить ефективність переконливим зображення природи як основи для змалювання досягнень людини у героїчному епосі [13].

До огляду критичних праць Роксолана Петрівна включила низку досліджень Р. Мена, який детально аналізує образність весільних пісень і народних звичаїв, що дає змогу провести паралель між “Словом” і “Задонщиною”. Р. Мен простежує зв'язки твору зі слов'янським фольклором, доводить, що образність весільних пісень і весільного обряду вплинула на деякі місця “Слова”, а особливо на Сон і Золоте Слово Святослава Всеволодовича [13]. У 1984 р. Р. Мен захистив докторську дисертацію "Oral composition in The Slovo o Polku Igoreve", у якій зіставляє поему з усною традицією Київської Русі [11] та трактує пам'ятку як усну епічну пісню, що виникла у контексті багатовікової епічної традиції.

Згадує Роксолана Зорівчак у своїх працях і дисертацію В. Сайковича "The Tale of Igor" studies on the question of its authenticity: Trends in the history of its criticism", представлену 1953 р. в Університеті Пенсильванії (Філадельфія), яка головно розкривала історичні, ідеологічні та лінгвістичні проблеми, пов'язані із пам'яткою та іiі місцем в контексті культури Київської Русі [13].

Не могла оминути увагою Роксолана Петрівна і питання автентичності твору, зазначаючи, що із розпадом Радянського Союзу відповідна дискусія набула нового й сильнішого розмаху [13]. На XI Міжнародному конгресі славістів у Братиславі 1993 р. американський дослідник В. Шамшула виступив із доповіддю, у якій, услід за А. Мазоном, котрий трактував пам'ятку як підробку пізніших віків [12], заперечив автентичність твору. Жоден славіст із присутніх на конгресі не вступив у дискусію із доповідачем, а текст його доповіді опублікували у повному обсязі у збірці матеріалів Конгресу. 
У всьому світі “Слово” викликає захоплення й подив своєю ідейною значущістю та художньою красою. Його перекладають багатьма мовами, але чимало ще треба зробити у дослідженні пам'ятки і не лише філологам та перекладознавцям, а й історикам, палеографам, текстологам, а також фахівцям інших галузей науки. Бо саме вагомі наукові дослідження “Слова”, надруковані в англомовних журналах і наукових збірниках, як наголошувала Роксолана Зорівчак, $\epsilon$ найефективнішим способом утвердити трактування й сприйняття "Слова" в англомовному академічному світі як цінної пам’ятки української культури.

\section{СПИСОК ВИКОРИСТАНОЇ ЛІТЕРАТУРИ}

1. Жлуктенко Ю. А. “Слово о полку Игореве в английском переводе”. Теория и практика перевода. Pесп. межвед. науч. сб. Киев : Высшая школа, 1985. Вып.12. С. 3-10.

2. Зорівчак Р. П. “Слово о полку Ігоревім” в англомовному світі (переклади, критичні праці) / Третій міжнародний конгрес украӥністів (Харків, 26-29 серпня 1996 р.): Тези і повідомлення. Харків : Око, 1996. Т. 1. Мовознавство. С. 304-310.

3. Зорівчак Р. П. “Слово о полку Ігоревім” у англомовному світі: переклади, критичні праці. Іноземна філологія: Укр. наук. зб. Львів : Вид. центр ЛНУ ім. І. Франка, 1997. Вип.110. С. 116-124.

4. Слово о поході Ігоревім Ігоря сина Святославового внука Олегового / Переднє слово, пер. та прим. П. Салевича. Львів, 1999. 78 с.

5. Яценко Б. “Слово о полку Ігоревім” та його доба (комплексне дослідження). Київ : Вид-во імені Олени Теліги, 2000. 256 с.

6. Яценко Б. И. Кто такой Борис Вячеславич “Слова о полку Ігореве?” Труды отдела древнерусской литературы Института русской литературы Пушкинского Дома. Москва; Ленинград, 1976. Т. ХХХІ. С. 296-304.

7. Яценко Б. И. Лаврентьевская повесть о походе Игоря Святославича в 1185 году. Рус. лит. 1985. № 3. С. 31-42.

8. Яценко Б. И. Черниговская повесть о походе Игоря Святославича в 1185 году. Исследования "Слова о полку Игореве”. Ленинград, 1986. С. 38-57.

9. Яценко Б. І. Про “золоте слово” Святослава Київського. Рад. літературознавство. 1976. № 5. С. 53-59.

10. Яценко Б. І. Про Троянь. Архіви України. Київ, 1970. № 6. С. 34-43.

11. Mann R. Oral composition in the Slovo o polku Igoreve: Ph. D. diss. Univ. of Kansas, 1984.

12. Mazon A. Le Slovo d'Igor. Travaux publies par l'institut d'etudes slaves. Paris : Droz, 1940. Vol. XX. 123 p.

13. Zorivchak R. "The Ihor Song" in the Anglophone world: Translation, scholarship. The Ukrainian Quarterly. 1999. Vol. LV. № 3-4. P. 260-283. 


\section{REFERENCES}

1. Zhluktenko Yu. A. "Slovo o polku Igoreve v angliyskom perevode" [The Tale of Ihor's Campaign in the English translation]. Teoriya i praktika perevoda [Theory and Practice of Translation]. Resp. mezhved. nauch. sb. Kiev : Vysshaya shkola., 1985. Vyp. 12. S. 3-10.

2. Zorivchak R. P. "Slovo o polku Ihorevim" v anglomovnomu sviti (pereklady, krytychni pratsi) [The Tale of Ihor's Campaign in the Anglophone World (translations and researches)]. Tretiy mizhnarodnyy kongres ukrainistiv (Kharkiv, 26-29 serpnya 1996 r.): Tezy i povidomlennya. Kharkiv: Oko, 1996. T. 1. Movoznavstvo. S. 304-310.

3. Zorivchak R. P. "Slovo o polku Ihorevim" u anglomovnomu sviti: pereklady, krytychni pratsi [The Tale of Ihor's Campaign in the Anglophone World: translations and researches]. Inozemna filologiya: Ukr. nauk. zb. Lviv : Vyd. tsentr LNU im. I. Franka, 1997. Vyp. 110. S. 116-124.

4. Slovo o pokhodi Ihorevim Ihorya syna Svyatoslavovoho vnuka Olehovoho[The Tale of Ihor's Campaign, the Son of Svyatoslav and the grandson of Oleh] / Peredn. slovo, per. ta prym. P. Salevycha. Lviv, 1999. 78 s.

5. Yatsenko B. "Slovo o polku Ihorevim" ta yoho doba (kompleksne doslidzhennya) [The Tale of Ihor's Campaign and its epoch]. Kyiv : Vyd-vo imeni Oleny Telihy, 2000. 256 s.

6. Yatsenko B. I. Kto takoi Boris Viatcheslavovich "Slova o polku Igoreve"? [Who is Boris Viatcheslavovich in The Tale of Ihor's Campaign]. Trudy otdela drevnerusskoi literatury Instituta russkoi literatury Pushkinskii Dom. Moskva; Leningrad, 1976.T. XXXI. S. 31-42.

7. Yatsenko B. I. Lavrentjevskaia povestj o pohode Igoria Sviatoslavicha v 1185 godu [Laurentian chronicle about the Tale of Ihor Sviatoslavich Campaign in 1185]. Rus. lit. 1985. № 3. S. 31-42.

8. Yatsenko B. I. Chernigovskaia povestj o pohode Igoria Sviatoslavicha v 1185 godu [Chernigov chronicle about The Tale of Ihor's Campaign in 1185]. Issledovania "Slova o polku Igoreve" [Research on The Tale of Ihor's Campaign]. Leningrad, 1986. S. 38-57.

9. Yatsenko B. I. Pro "zolote slovo" Svyatoslava Kyivs'koho [About the "word of gold" of Svyatoslav Kyivs’kyi]. Rad. literatyroznavstvo. 1976. № 5. S. 53-59.

10. Yatsenko B. I. Pro Troyan' [About Troyan']. Arhivy Ukrainy. Kyiv, 1970. № 6. S. 34-43.

11. Mann R. Oral composition in the Slovo o polku Igoreve: Ph. D. diss. Univ. of Kansas, 1984.

12. Mazon A. Le Slovo d'Igor. Travaux publies par l'institut d'etudes slaves. Paris : Droz, 1940. Vol. XX. 123 p.

13. Zorivchak R. "The Ihor Song" in the Anglophone world: Translation, scholarship. The Ukrainian Quarterly. 1999. Vol. LV. № 3-4. P. 260-283. 


\title{
"WITH ANGUISH OF OUR "SLOVO" SHE HAS ANGUISHED": THE ANALYSIS OF PROFESSOR ROKSOLANA ZORIVCHAK'S CONTIBUTION TO THE STUDIES OF "THE TALE OF IHOR'S CAMPAIGN"
}

\author{
Ruslana Sytar \\ Ivan Franko National University of Lviv, \\ 1, Universytetska Str., Lviv, Ukraine, 79000 \\ sytarruslana212@gmail.com
}

The article provides data on the research on "The Tale of Ihor's Campaign" by Professor Roksolana Zorivchak. She managed to continue the studies started by her teacher Professor Yu. Zhluktenko and is the first who compiled the list of Anglophone translations of this masterpiece and provided their critical overview. Roksolana Zorivchak does not limit her research only to the translations of "Slovo" but also makes a comprehensive analysis of critical works on it. She praised an extremely valuable article by D. Ward on the translation of this masterpiece ("On translating "Slovo o polku Igoreve""): the researcher dwells on the "obscurities" of the poem, on the reproduction of the functions of expressive syntax, archaisms, verbal images and prosody. Roksolana Zorivchak mentions also the doctoral thesis of A. Baker, "Sea and steppe imagery in Old English and Old Russian epic"(1976). In her opinion, "Slovo" and the Old English epic "Beowulf" serve as convincing evidence of the effectiveness of descriptions of nature as the background for the picturing of the achievements of people in heroic poetry. Citing in detail the textual material, the author demonstrates that pantheism in "Slovo" is very deep, while in "Beowulf" the sea is personified only negligibly. Roksolana Zorivchak analyses also some works by R. Mann who translated the poem and in 1984 defended a doctoral thesis "Oral composition in the "Slovo o polku Ihorevi" in the University of Kansas. In this dissertation, he related the poem to the oral tradition of Kyivan Rus'. R. Mann reviews in detail the imagery of wedding songs, wailing for the dead and other popular traditions, echoes of which can be perceived in the poem. The researcher also makes a certain parallel between "Slovo" and "Zadonshchyna", offers his interpretation of obscure words and expressions and stresses that this was, indeed, an oral work. Professor Roksolana Zorivchak paid her attention to another doctoral dissertation on the poem in the Anglophone world defended by V. Saykovich - "The Tale of Igor. Studies on the question of its authenticity: Trends in the history of its criticism" (University of Pennsylvania, Philadelphia, 1953). This dissertation focuses on the historical, ideological and linguistic problems surrounding "Slovo" and its place in the context of the culture of Kyivan Rus'.

Key words: Anglophone Sloviana, translation, Old Rus' epos, authenticity, The Tale of Ihor's Campaign, obscure words. 